\title{
Paleomagnetism of Quaternary sediments from Anholt, Denmark: Onset of the Blake Event and Eem
}

\author{
NIELS ABRAHAMSEN
}

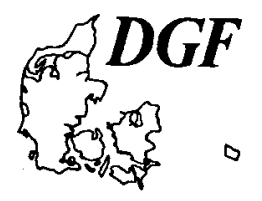

\begin{abstract}
Abrahamsen, N.: Paleomagnetism of Quaternary sediments from Anholt, Denmark: Onset of the Blake Event and Eem. Bulletin of the Geological Society of Denmark, Vol 42, pp. 96-104, Copenhagen, 1995-10-31. https://doi.org/10.37570/bgsd-1995-42-09

The c. $70 \mathrm{~m}$ non-marine Weichselian sands and clays from two consecutive borings, Anholt II and III, show normal polarity and inclinations somewhat shallower (c. $115^{\circ}$ ) than the axial dipole field value, which may be explained by a moderate compression of the sediment. Most of the marine shallow water silty clays of the Saalian (isotope stage 6) and Eemian (isotope substage $5 \mathrm{e}$ ) sections $(74-81 \mathrm{~m}$ ) also show normal inclinations, except for two samples at the very top part of the recovered Eemian stage, which are distinctly reversely magnetized. The reversed section of the Pleistocene sediments (in Anholt III) is interpreted to belong to the earliest part of the short reverse geomagnetic Blake event. Correlation via biostratigraphy and oxygen isotopes provides an estimate for the onset of the Blake reversal at about $123 \mathrm{ka}$ which, together with the termination date of $117 \mathrm{ka}$ from Lac de Bouchet, possibly suggest an age of about 123-117 for the Blake reversal.
\end{abstract}

Niels Abrahamsen, Department of Earth Sciences, Aarhus University, Finlandsgade 8, DK-8200 Aarhus N, Denmark. 11th March, 1994.

\section{Introduction}

This paper presents magnetic results from Saalian and Weichselian sediments sampled in the Anholt II and III drill cores, and especially deals with the short reversed geomagnetic Blake event. The small Danish island, Anholt, is situated on the northeastern rim of the Fennoscandian Border Zone, a complicated faulted zone (Liboriussen et al. 1987) which separates the Fennoscandian Shield from the deeply subsided Norwegian-Danish regional sedimentary basin (Figs 1-2). In the Late Quaternary the northernmost part of Jutland and Kattegat formed a structurally induced local basin (Lykke-Andersen 1987) defined from borings and various open sections (e.g. Bahnson et al.1974; Knudsen 1985; Lykke-Andersen \& Knudsen 1990).

The material recovered from an early boring from 1943 (Anholt I) was of rather poor quality (Lykke-Andersen 1990). Therefore, new borings to a combined depth of $306 \mathrm{~m}$ (Anholt II, III \& IV) were made in 1990 in connection with the GeoKat project (Nielsen 1992). Apart from investigations of the Anholt cores, local and regional seismic (Lykke-Andersen et al. 1993, Gyldenholm et al. 1993, Vangkilde-Pedersen et al. 1993) and marine magnetic surveys (Abrahamsen et al. 1992) were also performed to obtain stratigraphical and structural information about the region. With respect to Quaternary magnetostratigraphy in Denmark only magnetic secular variation results from Late- and Post-Glacial sediments have yet been published (e.g. Abrahamsen \& Knudsen 1979; Abrahamsen \& Readman 1980, 1987; Readman \& Abrahamsen 1988; 1990; Brehmer 1990).

\section{Sampling and magnetic methods}

The new borings were made by a rotational drilling technique with cored sections of one meter in length. Due to technical difficulties during the boring process four holes were made. As the sampled parts of the borings overlap only little, and as the holes are situated only a few meters apart, the combined core sections may be regarded as originating from one combined core (further details in Lykke-Andersen et al. 1993, Seidenkrantz 1993a,b). The magnetic specimens were sampled in the laboratory using cylindrical polystyrene beakers, $22 \mathrm{~mm} \times 25 \mathrm{~mm}$ in length and diameter, which were pressed into the rather stiff sediment orthogonal to the axis of the core. The core was not azimuthally oriented during the boring, and as only a few specimens were sampled from each section for magnetic investigations, the declination would be of no significance, leaving only the inclination and the magnetic remanence of interest for further studies. The samples were sealed in airtight bags to prevent drying out, and stored 


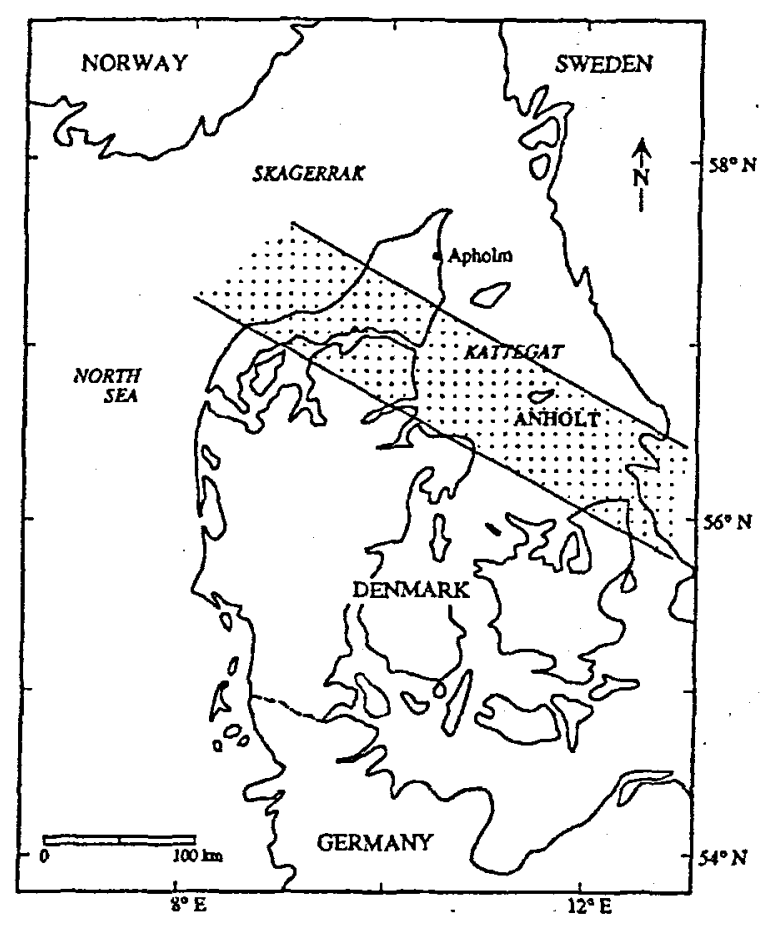

Fig. 1. Index map of Denmark, showing the situation of the island Anholt, and the Sorgenfrei-Tornquist/Fennoscandian Border Zone (dotted). The zone is a strongly faulted and tectonically still active area, separating the deeply subsided Danish sediment basin from the elevated Precambrian basement area to the northeast.

in a reduced magnetic field until the laboratory measurements were undertaken. A total of 119 magnetic samples from the Quaternary sediments have been investigated, 68 being Weichselian, and 51 Saalian and Eemian. The dating and biostratigraphy, as based upon benthic foraminifera and stable isotopes, is discussed in detail by Seidenkrantz (1993a, b).

The lithology and lithostratigraphy of the Quaternary part is summarized in Fig. 3, while a full description of the lithostratigraphy is given by Nielsen (1992). The lithology of the sequence is quite varied, the grain size varying from clay to gravel and till, but only the more finegrained parts (clay, silty clay and silt) were sampled magnetically in order to reduce inclination errors due to the coarser grainfractions. Magnetic sampling of the older (Jurassic) sediments was also made, the results being reported elsewhere.

The remanent magnetization (inclination and intensity) was measured on a Molspin spinner magnetometer, and a partial stepwise magnetic cleaning in alternating fields was performed by two axis tumbling in a Molspin AF-demagnetizer to remove possible soft recent magnetic components. All specimens were AFcleaned up to $30 \mathrm{mT}$, and selected specimens were further demagnetized up to $100 \mathrm{mT}$.

\section{Weichselian sediments}

The Weichselian sediments (Nielsen 1992; Seidenkrantz 1993a, b) were found from the surface down to about $70 \mathrm{~m}$. They were dominated by sandy and clayey, mostly non-marine, fluviatile sediments. Weichselian tills were not found in the borings, but tills may be present in the elevated topography of about $+40 \mathrm{~m}$ just south of the site.

The NRM (natural remanent magnetization) intensity varies between 2 and $62 \mathrm{~mA} / \mathrm{m}$ (Fig. 4), with most values between 8 and $20 \mathrm{~mA} / \mathrm{m}$ for the sandy parts between 20 and $38 \mathrm{~m}$ depth. The cluster of relative high values between 30 and $50 \mathrm{~mA} / \mathrm{m}$ at 43 to $45 \mathrm{~m}$ depth are associated with silty clays.

Most values of inclination (Fig. 5) are in the range $45^{\circ}$ to $70^{\circ}$, but the scatter was too high to enable a secular variation pattern to be identified. The mean inclination of the 60 samples with inclination above $35^{\circ}$ was $57^{\circ} \pm 11^{\circ}$, which is somewhat smaller than the central axial dipole inclination at the site, $\mathrm{I}_{0}=71.8^{\circ}$. Thus a post-remanence shallowing of the inclination seems to have occurred. The shallowing is most likely due to compression from the loads of a younger overriding (young Weichselian) ice, which may have attained a thickness of the order of $1 \mathrm{~km}$. The load of the younger sediments must have been less important as a compacting factor, compared to the load of the overriding ice.

\section{Saalian and Eemian sediments}

Between 74 and $81 \mathrm{~m}$ a sequence of marine silty clays of Saalian to Eemian age (Seidenkrantz 1993a) was found. The NRM intensity (Fig. 6) varied between 2

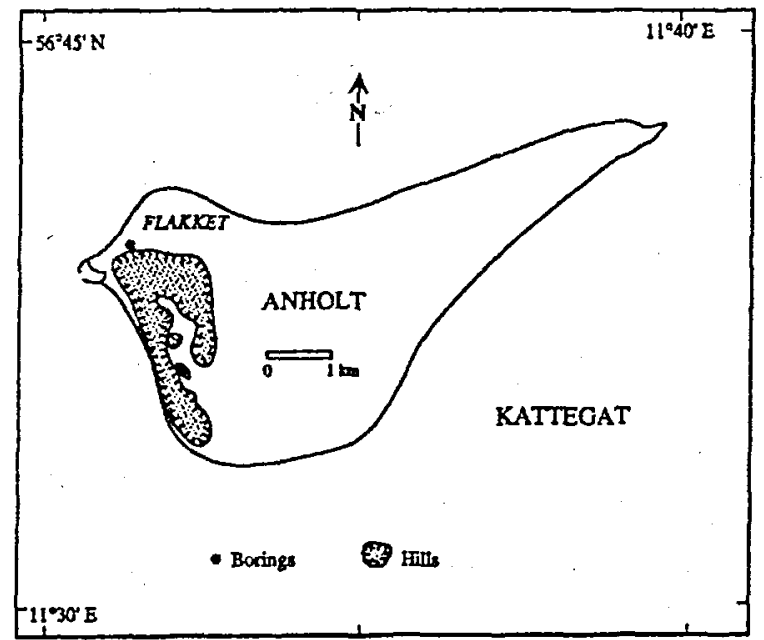

Fig. 2. The small island Anholt, with the drilling site indicated. 


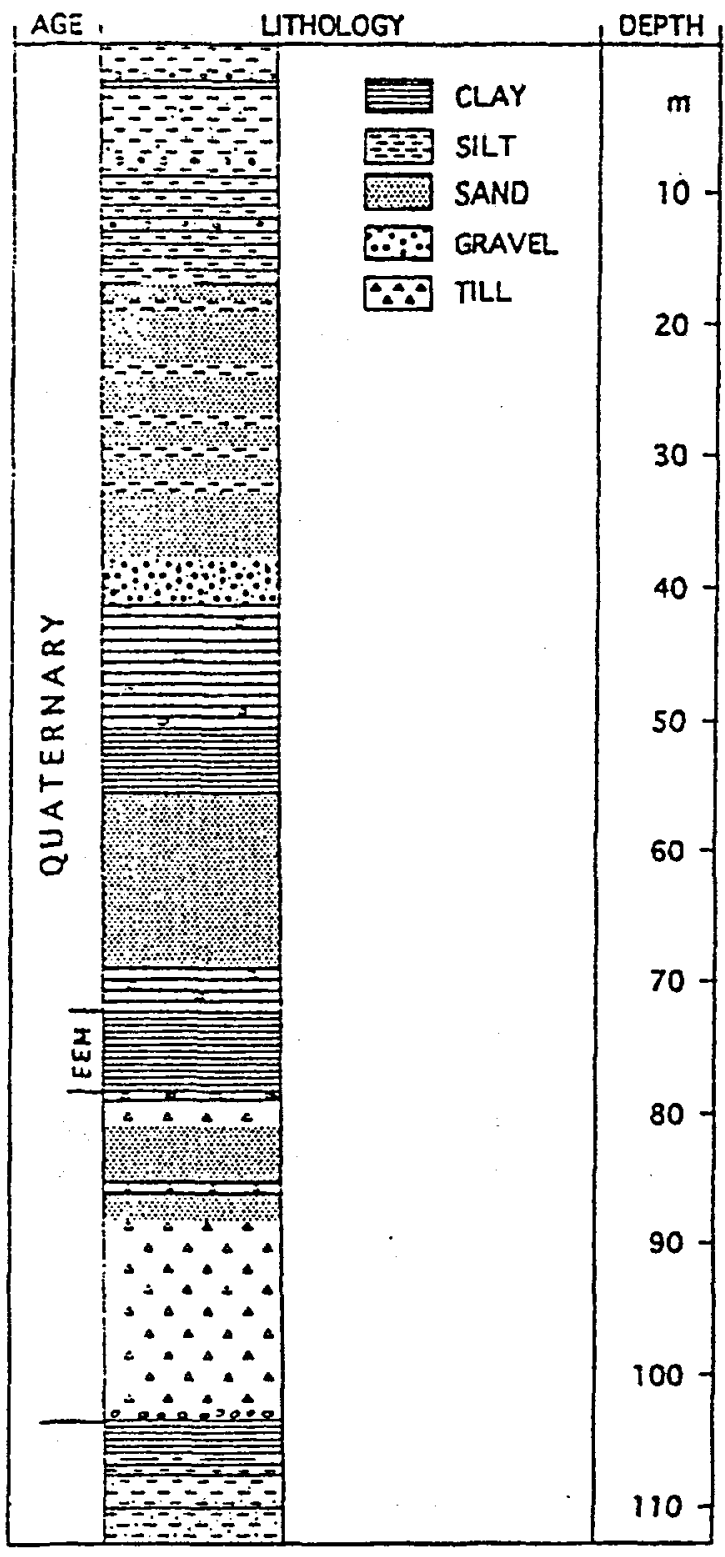

Fig. 3. Lithostratigraphy of the Quaternary part of the Anholt IV boring (modified from Nielsen 1992).

and $60 \mathrm{~mA} / \mathrm{m}$, with most values between 6 and $20 \mathrm{~mA} /$ $\mathrm{m}$ for the sandy and clayey parts of the Saalian sediments between 77 and $81 \mathrm{~m}$ depth. The Eemian marine silty clays between 74 and $76 \mathrm{~m}$ showed generally higher values, typically between 30 and $60 \mathrm{~mA} /$ m.

The mean inclination of the 46 samples with inclination above $35^{\circ} \pm$ is $62^{\circ} \pm 8^{\circ}$ (Fig. 7). Shallowing of the inclination was thus less than in the Weichselian, which may be due to more silt dispersed in the clay matrix. Two outliers at $76.50\left(\mathrm{I}=-58^{\circ}\right) \mathrm{m}$ and $77.90\left(\mathrm{I}=12^{\circ}\right) \mathrm{m}$ are marked with question marks as they are both surrounded by samples of more typical normal inclinations, and are likely to be due to disturbance by sampling. More interesting are the two topmost samples at $74.76 \mathrm{~m}$ (with a negative inclination of $-46^{\circ}$ ) and at $74.87 \mathrm{~m}$ (with $\mathrm{I}=-59^{\circ}$ ), from the top part of the Eemian, which were recovered in Anholt III. These samples belong to foraminiferal zone $\mathrm{G}$ and isotope event 5.51 (Martinson et al. 1987; Seidenkrantz 1993a), and thus have an age of c. 123000 years (Seidenkrantz 1993a). Based upon foraminifers and rate of deposition estimates, Seidenkrantz suggests that only the lower $2 / 3$ of the Eemian (i.e. c. 10000 years of a total duration of c. 15000 years) is present in Anholt III.

Typical behaviour by AF demagnetization of three samples is shown in Fig. 8. Sample AN3-75.20 (boring Anholt III, depth $=75.20 \mathrm{~m}$ ), which is from the top of the normal polarity part of the late Saalian-early Eemian sequence (cf. Fig. 6), shows a typical good directional cluster up to $40 \mathrm{mT}$, above which the direction becomes more unstable. Samples AN3-74.87 and AN3-74.76 are both reversely magnetized and well behaved, with m.d.f. (median destructive fields) of 30 and $40 \mathrm{mT}$, respectively. After initial removal of viscous components between 0 and $10 \mathrm{mT}$, the direction is stable up to 40 and $50 \mathrm{mT}$, respectively. The m.d.f. as well as the shape of the intensity decay curves indicate, that the dominant remanence carriers are multi domain (finegrained) magnetites, probably of detrital origin.

\section{The Blake Event}

The geomagnetic Blake Event, or rather episode, is a fairly short polarity reversal which has been approximately dated to between 104000 and 117000 years BP (Tarling 1983).

Although suggested by Denham (1976), and Denham et al. (1977) to be of restricted regional extent only, the Blake episode now appears to have been recorded rather globally (or at least in about a dozen places on the northern hemisphere), and in quite different environments such as deep sea sediments, shallow sea sediments, lacustrine sediments, continental loess, and volcanic pyroclastics, as summarised in Table 1.

The estimates of age as well as of duration of the Blake event differ somewhat in the different investigations, constrained by different methods (such as sedimentation rates, reversal chronology, microfossils, oxygen isotopes, radiometric and fission-track ages). The magnetic records for this event are not always complete (Thuveny et al. 1990), or of good quality, which may be due to low intensity, as in the case of the Grand Pile (Ellingsen \& Løvlie 1992). Also the morphology of the Blake episode is not well constrained, as some data show only one continuous reversal (Tucholka et al. 1987), while others show two 


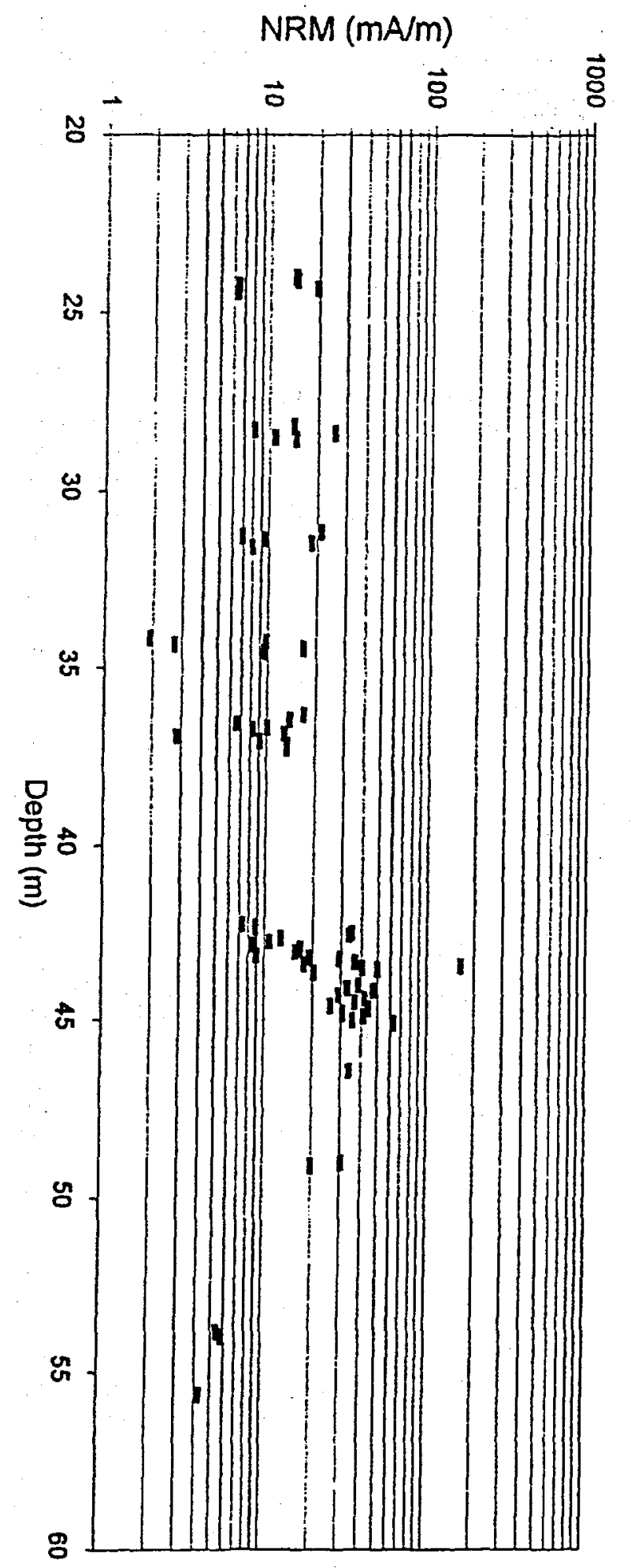

Fig. 4. NRM intensity of samples from the Weichselian part of the Anholt borings.

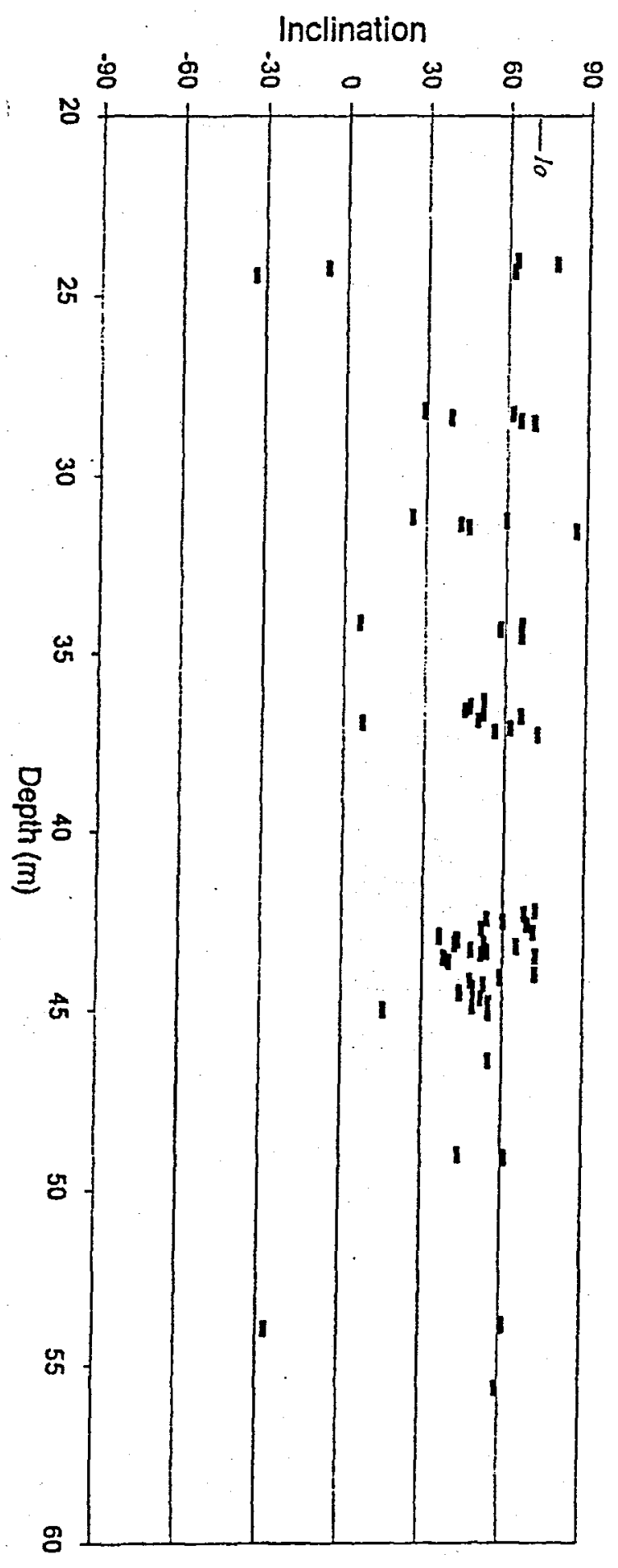

Fig. 5. Inclination of Weichselian samples from Anholt II and III (after partial demagnetization in alternating fields of 20 to $30 \mathrm{mT}$ ). 

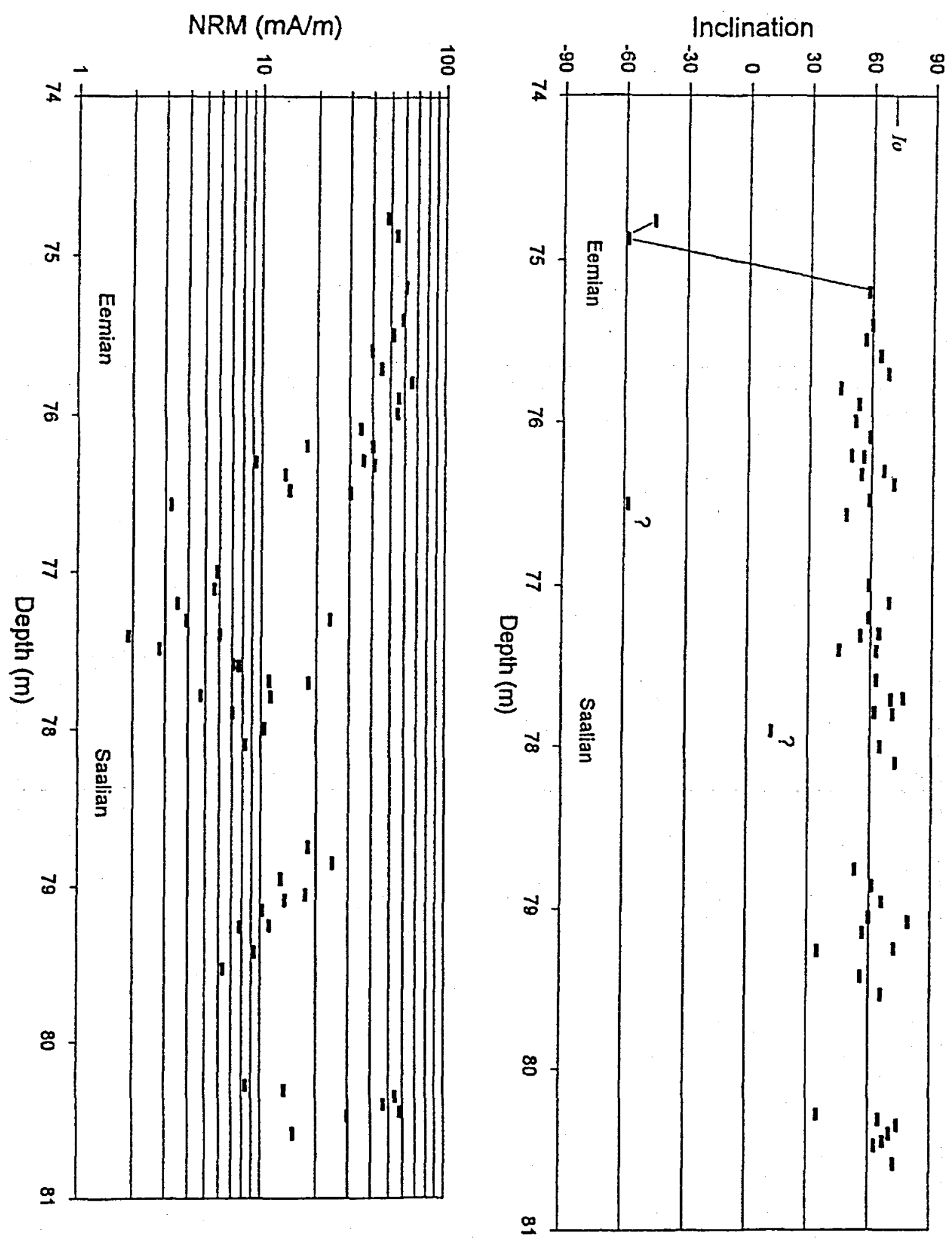

Fig. 6. NRM intensity of samples from the Eemian-Saalian sequence.

Fig. 7. Inclination of samples from the Eemian-Saalian sequence in Anholt II and III. $\mathrm{I}_{0}$ is the inclination of the central axial dipole field. 

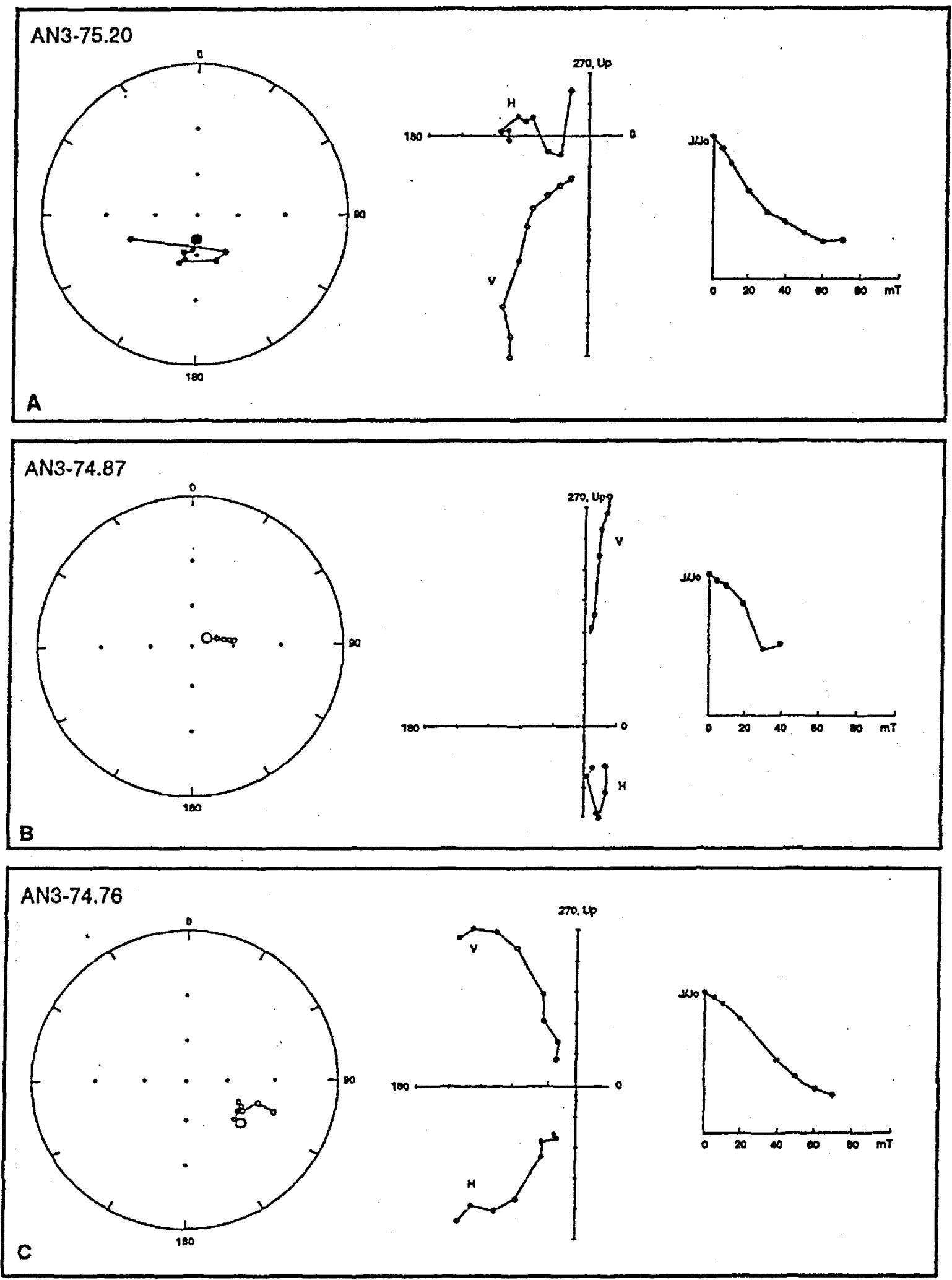

Fig. 8. Stereographic projection (left, solid (open) signature = positive (negative) inclination), normalized magnetic intensity decay (right, scale in $\mathrm{mT}$ ) and Zijderveld orthogonal plots (center) by alternating field demagnetization of samples from Anholt III. A. Sample AN3-75.20 with normal polarity, situated just below the top part of the reversed Saalian section (cf. Fig. 7). B. Sample AN3-74.87 with reversed polarity, from the reversed top part of the Saalian section (cf. Fig. 7). C. Sample AN3-74.76 with reversed polarity, from the reversed part of the Saalian section (cf. Fig. 7). 
Table 1. Records of the Blake reversal.

\begin{tabular}{|c|c|c|c|}
\hline $\begin{array}{l}\text { Environment \& } \\
\text { material }\end{array}$ & Area & Age and duration $(\mathrm{ka})$ & Reference \\
\hline marine deep sea sediments & Caribbean \& Indian Ocean & $105-114,5-7 \& 12 ?$ & Smith \& Foster 1969 \\
\hline continental loess & Czechoslovakia (inferred) & Kukla \& Koci 1972 & \\
\hline lacustrine sediments & Japan Lake Biwa & (inferred) & $\begin{array}{l}\text { Yasakawa et al. 1973; } \\
\text { Yasakawa } 1974\end{array}$ \\
\hline pyroclastics ignimbrite, tuf & Japan, Indonesia & $110 \pm 10$ & $\begin{array}{l}\text { Sasajima 1973; } \\
\text { Sasajima et al. } 1984\end{array}$ \\
\hline marine deep sea sediments & Caribbean & (inferred) & $\begin{array}{l}\text { Denham 1976; } \\
\text { Denham et al. } 1977\end{array}$ \\
\hline continental loess & Poland & $120 \pm 18$ & $\begin{array}{l}\text { Tucholka 1977; } \\
\text { Wintle } 1983\end{array}$ \\
\hline continental loess & Tadzhikistan & $110 \pm 13$ & Davis et al. 1980 \\
\hline shallow marine sediments & Italy & $105-155$ & Creer et al. 1980 \\
\hline marine deep sea sediments & Mediterranean & $117 \pm 0.7, \quad 5.2 \pm 2.7$ & Tucholka et al. 1987 \\
\hline lacustrine sediments & Oregon Pringle Falls & $(105,114)$ & Herrero-Bervera 1989 \\
\hline lacustrine sediments & France Lac de Bouchet & $>117$ & Thuveny et al. 1990 \\
\hline shallow marine sediments & Denmark Anholt & $<123$ & This work \\
\hline
\end{tabular}

consecutive short reversals (Denham 1975; Creer et al. 1980; Herrero-Bervera et al. 1989).

In Anholt III (Fig. 7) the two reversed samples at 74.87 and $74.76 \mathrm{~m}$, on top of the normal sample at $75.20 \mathrm{~m}$ depth, define the minimal stratigraphical reversed interval of the core to be at least between 0.11 and $0.44 \mathrm{~m}$. Adopting an average rate of deposition as $0,33 \mathrm{~m} / \mathrm{ka}$ (Seidenkrantz 1993a), based upon correlation via microfossils to another boring at Apholm in Vendsyssel (Fig. 1), and presuming the total duration. of the Eemian stage to be $\mathbf{1 5 0 0 0}$ years, the duration of the reversed interval in the core is between 330 and 1330 years, i.e. of the order of 1000 years. It is therefore most likely that, in Anholt III, only the oldest part of the Blake reversal is seen.

Combining the above suggested approximate time of $123000 \mathrm{BP}$ for the onset of the Blake event, and its termination to $117000 \mathrm{BP}$, as estimated from the Lac de Bouchet (Thuveny et al. 1990), an approximate time range for the Blake reversal is obtained as $117-123 \mathrm{ka}$. This estimate is in fair concordance with the majority of the other data about the age and duration of the Blake reversal as summarised in Table 1.

\section{Conclusions}

1)The paleomagnetic measurements of the Weichselian sediments in the c. $70 \mathrm{~m}$ non-marine Weichselian sands and clays of the two borings Anholt II and III show normal polarity.

2) Inclinations of the Weichselian are somewhat shallower (c. $15^{\circ}$ ) than the axial dipole field value of the site, which may be explained by a moderate compression of the sediment after acquisition of the remanence.

3) Most of the marine shallow water silty clays of the Saalian (isotope stage 6) and Eemian (isotope substage 5e) section $(74-81 \mathrm{~m}$ ) show normal inclinations.

4) Two samples in the very top part of the recovered Eemian stage, however, are distinctly reversely magnetized. The reversed part of Anholt III can possibly be interpreted as belonging to the earliest part (duration of the order of 1000 years) of the short reverse geomagnetic Blake event.

5) Correlation, via biostratigraphy and oxygen isotopes (Seidenkrantz 1993a), offers an estimate of the onset 
of the Blake reversal to have occurred about 123 $000 \mathrm{BP}$.

6) Combining the information from the Anholt borings with that of Lac de Bouchet, an age of 123000 and $117000 \mathrm{BP}$ for the onset and the termination of the Blake reversal, respectively, is suggested. The derived duration of only c. $6000 \mathrm{y}$ is exceptionally short for a globally recorded polarity event (e.g. Abrahamsen \& Sager 1994).

\section{Acknowledgements}

The magnetic sampling was done by Marit-Solveig Seidenkrantz, and part of the magnetic measurements were made by Heri Ziska, both of whom are acknowledged. The work was financially supported by the Danish Natural Science Foundation as part of the Mag$\mathrm{Kat} / \mathrm{GeoKat}$ projects.

\section{References}

Abrahamsen, N., Christensen, A. N., Olesen, A., VangkildePedersen, T., Breiner, N., Lykke Andersen, H. \& Holm Jacobsen, B. 1992: MAGKAT: Marinmagnetiske undersøgelser i Kattegat. Dansk Geologisk Forening, Årsskrift for 1990-91, 155-158.

Abrahamsen, N. \& Knudsen, K. L. 1979: Indication of a geomagnetic low-inclination excursion in supposed Middle Weichselian Interstadial marine clay at Rubjerg, Denmark. Physics of the Earth and Planetary Interiors 18, 238-246.

Abrahamsen, N. \& Readman, P. W. 1980: Geomagnetic variations recorded in Older ( $>23000 \mathrm{BP}$ ) and Younger Yoldia Clay (-14 000 BP) at Nørre Lyngby, Denmark. Geophysical Journal of the Royal astronomical Society $62,329-344$.

Abrahamsen, N. \& Readman, P. W. 1987: Quaternary magneto-stratigraphy in Denmark. Boreas 16, 373-380.

Abrahamsen, N. \& Sager, W. W. 1994: Cobb Mountain geomagnetic polarity event and transition in three deepsea sediment cores from the Lau Bassin. In: Hawkins, J., Parson, L., Allen, J., et al.: Proceedings of the Ocean Drilling Program, Scientific Results 135, 737-761.

Bahnson, H., Petersen, K. S., Konradi, P. B. \& Knudsen, K. L. 1974: Stratigraphy of Quaternary deposits in the Skærumhede II boring: lithology, molluses and foraminifera. Danmarks geologiske Unders $\emptyset$ gelse Årsskrift for $1973,27-62$.

Brehmer, A. C. 1990: En sedimentologisk og geokemisk unders $\emptyset$ gelse samt magnetostratigrafisk datering af en sen Mellem-Weichsel issøaflejring i Istebjerg lergrav, NVSjælland. Dansk Geologisk Forening, Årsskrift for 1989, 49-54.

Creer, K. M., Readman, P. W. \& Jacobs, A. M. 1980: Palaeomagnetic and palaeontological dating of a section at Gioia Tauro, Italy: Identification of the Blake event. Earth and Planetary Science Letters 57, 289-300.
Davis, R. S., Raniv, V. A. \& Dodonov, A. E., 1980: Early man in Soviet Central Asia. Scientific American 243, 92102.

Denham, C. R., 1975: Blake polarity episode in two cores from the Greater Antilles Outer Ridge. Earth and Planetary Science Letters 29, 422-434.

Denham, C. H., Anderson, R. F. \& Bacon, M. P. 1977: Paleomagnetism and radiochemical age estimates for late Brunhes polarity episodes. Earth and Planetary Science Letters 35, 384-397.

Ellingsen, K. L. \& Løvlie, R. 1992: Magnetomineralogy and revised excursions for the last Interglacial-Glacial Cycle in the Grand Pile lacustrine sequence, France. Quaternary Research 37, 16-28.

Gyldenholm, K. G., Lykke-Andersen, H. \& Lind, G. 1993: Seismic stratigraphy of the Quaternary and its substratum in southeastern Kattegat. Boreas 22, 319-327.

Herrero-Bervera, E., Helsley, C. E., Hammond, S. R. \& Chitwood, L. A. 1989: A possible lacustrine paleo-magnetic record of the Blake episode from Pringle Falls, Oregon, U.S.A. Physics of the Earth and Planetary Interiors 56, 112-123.

Knudsen, K. L. 1985: Correlation of Saalian, Eemian and Weichselian foraminiferal zones in North Jutland. Bulletin of the Geological Society of Denmark 33, 325-339.

Kukla, G. J. \& Koci, A. 1972: End of the last Interglacial in the loess record. Quaternary Research 2, 374-383.

Liboriussen, J., Ashton, O.\& Tygesen, T. 1987: The tectonic evolution of the Fennoscandian Border Zone in Denmark. Tectonophysics 137, 21-29.

Lykke-Andersen, A.-L. 1990: Foraminiferal stratigraphy of Quaternary deposits in boring no. 51.12 Anholt, Kattegat. Danmarks Geologiske Unders $\emptyset$ gelse, Serie B, 15, 140.

Lykke-Andersen, A.-L. \& Knudsen, K. L. 1991: Saalian, Eemian, and Weichselian in the Vendsyssel-Kattegat Region, Denmark. In: Andersen, B. G. \& Königsson, L.-K. (eds.): Late Quaternary Stratigraphy in the Nordic Countries 150.000-15.000. Striae 34, 135-140.

Lykke-Andersen, H. 1987: Thickness of Quaternary deposits and their relation to the pre-Quaternary in the Fennoscandian border zone in Kattegat and Vendsyssel. Boreas $16,369-371$.

Lykke-Andersen, H., Seidenkrantz, M.-S. \& Knudsen, K.L. 1994: Quaternary sequences and their relations to the pre-Quaternary in the vicinity of Anholt, Kattegat, Scandinavia. Boreas 22, 291-298.

Martinson, D. G., Pisas, N. G., Hays, J. D., Imbrie, J., Moore, Jr., Th. C. \& Shackleton, N. J. 1987: Age dating and the Orbital Theory of the Ice Ages: Development of a HighResolution 0 to 300,000 -Year Chronostratigraphy. Quaternary Research 27, 1-29.

Nielsen, O. B. 1992: Lithologi, lithostratigrafi og aflejringsmiljø i Anholtboringen. Dansk Geologisk Forening, Årsskrift for 1990-91, 67-72.

Readman, P. W. \& Abrahamsen, N. 1988. Palaeomagnetism of Post Glacial lake sediments from Skanderborg Sø,Jutland, Denmark. Physics of the Earth and Planetary Interiors 52, 177-192.

Readman, P. W. \& Abrahamsen, N. 1990: Geomagnetic secular variation from Holocene lake sediments of Sor $\varnothing$ S $\emptyset$, Denmark. Physics of the Earth and Planetary Interors 62, 4-18.

Sasajima, S., Nishimura, S. \& Hirooka, K. 1984: The Blake geomagnetic event as inferred from late Brunhes 
ignimbrites in southwest Japan and west Indonesia. Journal of Geomagnetism and Geoelectricity 36, 203-214.

Seidenkrantz, M.-S. 1993a: Benthic foraminiferal and stable isotope evidence for a "Younger Dryas-style" cold spell at the Saalian-Eemian transition, Denmark. Palaeogeography, Palaeoclimatology, Palaeoecology 102, 103 120.

Seidenkrantz, M.-S. 1993b: Foraminifera from the Quaternary sequence in the Anholt boring, Denmark. Boreas 22, 283-290.

Smith, J. D. \& Foster, J. H. 1969: Geomagnetic reversal in Brunhes normal polarity epoch. Science 163, 565-567.

Tarling, D. H. 1983: Palaeomagnetism. 379 pp. Chapman and Hall: London. huveny, N., Creer, K. M. \& Blunk, I. 1990: Extension of the Lac du Bouchet palaeomagnetic record over the last 120,000 years. Earth and Planetary Science Letters 97, 140-162.

Tucholka, P. 1977: Magnetic polarity events in Polish loess profiles. Biuletyn Institutu Geologicznego Warsawa, 305.

Tucholka, P., Fontugne, M., Guichard, F. \& Paterne, M. 1987: The Blake magnetic polarity episode in cores from the Mediterranean Sea. Earth and Planetary Science Letters 86, 320-326.

Vangkilde-Pedersen, T., Lykke-Andersen, H. \& Lind, G. 1993: Dislocated Quaternary deposits in southeastern Kattegat - glacial or gravitational phenomenon? Boreas 22, 329-336.

Wintle, A. 1983: Thermoluminescence, 63-75. In: Creer, K. M., Tucholka, P. \& Barton, C. E. (eds.), Geomagnetism of baked clays and recent sediments. 324 pp. Amsterdam: Elsevier.

Yasakawa, K. 1974: Reversals, excursions and secular variations of the geomagnetic field in the Brunhes normal polarity epoch. In Horie, S. (ed.): Palaeolimnology of the Lake Biwa and the Japanese Pleistocene, 2, 77.

Yasakawa, K., Nakajima, T., Kawai, N., Torri, M., Natsuhara, N. \& Horie, S. 1973: Palaeomagnetism of a core from Lake Biwa. Journal of Geomagnetism and Geoelectricity 25, 447-4. 


\section{Erratum}

In the article by N. Abrahamsen: Paleomagnetism of Quarternary sediments from Anholt, Denmark: Onset of the Blake Event and Eem, Vol. 42(1), pp. 96-104, read c. $15^{\circ}$ for c. $115^{\circ}$ in the abstract, second line (p. 96). 